\title{
TANGGUNG JAWAB NEGARA TERHADAP PENGAWASAN BANTUAN SOSIAL SELAMA PANDEMI COVID-19
}

\section{(STATE RESPONSIBILITIES AGAINST SUPERVISION SOCIAL ASSISTANCE DURING PANDEMIC COVID-19)}

\author{
Yusrizal $^{1}$ \\ ${ }^{1}$ Bagian Hukum Pidana, Fakultas Hukum, Universitas Malikussaleh \\ Kampus Bukit Indah, Jl. Jawa- Blang Pulo, Lhokseumawe, Kec. Muara Satu \\ Aceh, Indonesia, 34162 \\ Email: yusrizal@unimal.ac.id
}

\begin{abstract}
The Covid-19 pandemic condition requires the country to focus more on the protection of citizens especially regarding the management of social assistance. The insecurity arises because the cost is estimated for the Bansos is enormous. While monitoring the distribution of BANSOS funds is not strict. The purpose of this writing is to conceptually know the supervision of social assistance in a legal perspective along with the Community's role in supervision. The results of this study explained that the need for surveillance conducted by the public as well as by government agencies in charge of preventing corruption and examining the country's finances, especially to monitor the reallocate of the budget and its implementation in handling the pandemic Covid-19. The institution is the Corruption Eradication Commission (KPK), the Financial Audit Board (BPK), and the Financial and Development Supervisory Agency (BPKP).
\end{abstract}

Keywords: Government, social assistance, supervision, corruption

\section{Intisari}

Kondisi pandemi Covid-19 mengharuskan negara untuk lebih fokus dalam perlindungan warga negara terutama perihal pengeloaan bantuan sosial.Kerawanan itu muncul karena biaya yang dianggarkan untuk bansos sangat besar. Sementara pengawasan penyaluran dana bansos tidak ketat.Tujuan penulisan ini untuk mengetahui secara konseptual pengawasan bantuan sosial dalam perspektif hukum beserta peran masyarakat dalam pengawasan. Hasil kajian ini menjelaskan bahwa perlunya pengawasan yang dilakukan oleh masyarakat maupun oleh lembaga pemerintah yang bertugas mencegah tindakan korupsi dan memeriksa keuangan negara terutama untuk memantau realokasi anggaran dan implementasinya dalam penanganan Pandemi Covid-19. Lembaga yang dimaksud adalah Komisi Pemberantasan Korupsi (KPK), Badan Pemeriksa Keuangan (BPK), dan Badan Pengawasan Keuangan dan Pembangunan (BPKP).

Kata Kunci: Pemerintah, bantuan sosial, pengawasan, korupsi 


\section{A. Pendahuluan}

Penyebaran virus Covid-19 atau yang populer disebut virus Corona semakin meluas di seluruh penjuru dunia. Dampak dari penyebaran virus tersebut Indonesia juga terpapar dan terguncang akibatnya. Ditengah situasi yang semakin sulit dan pergerakan virus yang kian masif, maka dibutuhkan suatu penanganan yang konfrehensif baik dari negara. berkaitan dengan hal tersebut, maka pemerintah mengeluarkan suatu landasan hukum terkait kebijakan keuangan negara dalam mengatasi Pandemi Corona Virus Disease 2019 (covid-19).

Berdasarkan penjelasan Peraturan Pemerintah Pengganti Undang-Undang Republik Indonesia Nomor 1 Tahun 2020 tentang Kebijakan Keuangan Negara dan Stabilitas Sistem Keuangan Untuk Penanganan Pandemi Corona Virus Disease 2019 (covid-19) dan/atau Dalam Rangka Menghadapi Ancaman yang Membahayakan Perekonomian Nasional dan/atau Stabilitas Sistem Keuangan dijelaskan bahwa perkembangan pandemi Corona Virus Disease 2019 (covid-19) juga berpotensi mengganggu aktivitas perekonomian di Indonesia. Salah satu implikasinya berupa penurunan pertumbuhan ekonomi Indonesia yang diperkirakan dapat mencapai $4 \%$ (empat persen) atau lebih rendah, tergantung kepada seberapa lama dan seberapa parah penyebaran pandemi Corona Virus Disease 2019 (COVID-19) mempengaruhi atau bahkan melumpuhkan kegiatan masyarakat dan aktivitas ekonomi.

Namun, dari semua itu, kebijakan pemerintah yang tegas adalah kunci utama. Sampai saat ini, setiap orang memiliki pandangan dan pendekatan yang berbeda mengenai wabah ini. Jika kemudian penyebarannya semakin masif, pemerintah harus bertanggung jawab. Pemerintah telah mengucurkan dana yang cukup besar dalam penanggulangan wabah ini. Harus diperhatikan bahwa dana tersebut harus dioptimalkan untuk penanggulangan wabah. Jika terdapat penyelewengan atau penyalahgunaan anggaran, hal itu dapat memenuhi syarat sebagai tindak pidana korupsi dengan ancaman pidana mati. ${ }^{1}$ Dari berbagai dana yang dianggarkan sebagian besar digunakan untuk penyaluran bantuan sosial bagi masyarakat miskin, kelompok rentan serta masyarakat yang terdampak Pandemi Corona Virus Disease 2019 (covid-19).

Sementara itu Ketua Pusat Kajian Antikorupsi (Pukat) UGM, Oce Madril mengungkapkan, dana bansos dari pemerintah dalam berbagai bentuk merupakan sektor yang rawan terjadinya korupsi. Kerawanan itu muncul karena biaya yang dianggarkan untuk bantuan sosial umumnya sangat besar. Sementara pengawasan penyaluran dana bansos umumnya tidak ketat karena dianggap bantuan kepada masyarakat miskin atau kelompok-kelompok rentan. ${ }^{2}$

Melihat adanya kerawanan penyalahgunaan dana bantuan sosial kepada masyarakat, Komisi Pemberantasan Korupsi mengingatkan pemerintah terkait

\footnotetext{
${ }^{1}$ Muhammad Fatahillah Akbar, Tanggung Jawab Hukum dalam Wabah Corona, Kolom Koran Tempo, Tgl. 30 Maret 2020. Bisa diakses melalui https://kolom.tempo.co/read/ 1325429/tanggung-jawab-hukum-dalam-wabah- corona/full\&view=ok, Diakses Tgl. 9 Mei 2020

${ }^{2}$ Media Berita Satu, Terkait Bansos, KPK Kaji Temuan BPK Adanya Potensi Kerugian Negara Rp 843,7 M, Lihat juga dalam: https:/www.beritasatu.com/nasional/631075-terkait-bansoskpk-kaji-temuan-bpk-adanya-potensi-kerugian-negara-rp-8437-m, Diakses Tgl. 10 mei 2020
} 
dengan kepastian data dalam pemberian Bantuan Sosial kepada masyarakat dalam upaya mengatasi dampak pandemik global Corona Virus Disease 2019 (COVID19). KPK menuangkannya dalam Surat Edaran No. 11 Tahun 2020, tanggal 21 April 2020 tentang Penggunaan Data Terpadu Kesejahteraan Sosial (DTKS) dan data non-DTKS dalam pemberian Bantuan Sosial kepada masyarakat dalam upaya mengatasi dampak pandemik global Corona Virus Disease 2019 (COVID-19). ${ }^{3}$

KPK menyadari di tengah upaya peningkatan pemberian bantuan sosial baik yang diberikan oleh pemerintah pusat melalui kementerian/lembaga dan pemerintah daerah, ketepatan data sebagai dasar pemberian bantuan sangat penting. Terutama mengingat besarnya alokasi dana yang disiapkan pemerintah. Dari tambahan belanja pemerintah pusat pada APBN 2020 sebesar Rp405,1 Triliun, sebesar Rp110 Triliun atau 27\% akan dialokasikan untuk jaring pengaman sosial, termasuk di dalamnya dialokasikan untuk bansos kepada masyarakat yang terdampak covid-19. ${ }^{4}$

Demikian juga dari hasil refocusing kegiatan dan realokasi anggaran pemda per 16 April 2020, total anggaran yang direalokasikan yaitu sebesar Rp56,57 Triliun atau sebesar 5,13\% dari total APBD 2020 yaitu Rp1.102 Triliun. Dari Rp56,57 Triliun tersebut sebesar Rp17,5 Triliun atau sekitar 31\% dialokasikan untuk belanja hibah/bansos dalam upaya mengatasi dampak pandemik covid-19 di daerah. ${ }^{5}$

Selain itu, banyak juga pengaduan dimana masyarakat melihat tidak jelasnya prosedur dan persyaratan untuk menerima bantuan. Kemudian ada pula aduan karena kondisi masyarakat yang lebih darurat namun tidak terdaftar sebagai penerima bantuan dan terdaftar tapi tidak dapat menerima bantuan di tempat domisili karena KTP pendatang. ${ }^{6}$

Berdasarkan pemaparan diatas, maka penulis tertarik untuk mengkaji secara konseptual bentuk pengelolaan serta pengawasan dari anggaran yang begitu besar diperuntukkan untuk bantuan sosial dalam perspektif hukum beserta peran masyarakat dalam pengawasan. Hal ini ditandai oleh pelaporan terkait penyaluran bantuan soaial yang tidak merata di wilayah sasaran yang dirasakan oleh sebahagian besar warga masyarakat di Indonesia.

\section{B. Pembahasan}

\section{a) Bantuan Sosial dan Konsep Negara Kesejahteraan}

Menurut Bagir Manan bahwa Konsep negara kesejahteraan adalah negara atau pemerintah tidak semata-mata sebagai penjaga keamanan atau ketertiban masyarakat, tetapi memikul tanggung jawab utama untuk mewujudkan keadilan

${ }^{3}$ Komisi Pemberantasan Korupsi, KPK Ingatkan Pemerintah Pastikan Data Penerima Bantuan Sosial, Lihat Juga dalam https://www.kpk.go.id/id/berita/siaran-pers/1600-kpk-ingatkanpemerintah-pastikan-data-penerima-bantuan-sosial, Diakses Tg. 10 Mei 2020.

${ }^{4}$ Ibid

${ }^{5}$ Ibid

${ }^{6}$ Today Line, Ombudsman Terima Aduan Petugas Salurkan Bansos Minta Imbalan ke Penerima, lihat dalam https://today.line. me/id/pc/article/ Ombudsman+Terima+Aduan+ Petugas+Salurkan+ Bansos+Minta+Imbalan+ke+Penerima-wMNILG, diakses Tgl. 13 Mei 2020 
sosial, kesejahteraan umum, dan sebesar-besarnya kemakmuran rakyat. ${ }^{7}$ Sejalan dengan pendapat Bagir Manan, menurut Sjahran Basah, berkaitan dengan negara kesejahteraan tersebut, maka tujuan pemerintah tidak semata-mata di bidang pemerintahan saja, melainkan harus melaksanakan kesejahteraan sosial dalam rangka mencapai tujuan negara melalui pembangunan nasional. ${ }^{8}$

Tujuan dalam setiap kebijakan kesejahteraan adalah untuk mengatasi ekonomi sosial masyarakat dan dengan perpanjangan tantangan politik seperti kemiskinan, pengangguran dan usia tua diantaranya. Konsep negara kesejahteraan dapat ditelusuri kembali ke pasca perangperiode di dunia Barat. Hal ini berpendapat bahwa tujuan dari pengenalan pelayanan kesejahteraan adalah untuk melindungi masyarakat. ${ }^{9}$

Sebuah tantangan penting bagi penerapan kebijakan kesejahteraan sosial adalahpelembagaan layanan kesejahteraan adalah komitmen politik dan pengawasan. Tantangan lainnya termasukdan akuntabilitas, penyimpangan bantuan sosial, korupsi dan kurangnya pendanaan di tengah meningkatnya permintaan dan munculnyakebutuhan kesejahteraan sosial. Untuk mengimbangi Ketentuan Layanan kesejahteraan sosial, maka pemangku kepentingan secara strategis agar tidak hanya meningkatkan kapasitasnya untuk menyediakan layanan kesejahteraan sosial akan tetapi melembagakan mekanisme penyaluran bantuan sosial yang berkesinambungan yang menjamin kesejahteraan masyarakat. ${ }^{10}$

Ditengah Pandemi Corona Virus Disease 2019 (covid-19), peran negara memang dituntut untuk mewujudkan tujuannya sebagai negara kesejahteraan sebagaimana diamanatkan dalam Pembukaan Undang-Undang Dasar 1945, yaitu: "Membentuk suatu pemerintah negara Indonesia yang melindungi segenap bangsa Indonesia dan seluruh tumpah darah Indonesia, dan untuk memajukan kesejahteraan umum, mencerdaskan kehidupan bangsa, serta ikut melaksanakan ketertiban dunia yang berdasarkan kemerdekaan, perdamaian abadi dan keadilan sosial". " Salah satu wujud perwujudan bentuk kesejahteraan masyarakat adalah dengan diberikannya bantuan sosial ditengah pandemi tersebut.

Jika dilihat dari pengertiannya, maka bantuan sosial adalah dapat dikatakan sebagai salah satu jenis belanja pemerintah yang termasuk dalam klasifikasi ekonomi. Belanja bantuan sosial adalah pengeluaran berupa transfer uang, barang atau jasa yang diberikan oleh Pemerintah Pusat/Daerah kepada masyarakat guna melindungi masyarakat dari kemungkinan terjadinya risiko sosial, meningkatkan kemampuan ekonomi dan/atau kesejahteraan masyarakat. Pengertian risiko sosial sendiri adalah kejadian atau peristiwa yang dapat menimbulkan potensi terjadinya

\footnotetext{
${ }^{7}$ Bagir Manan, Politik Perundang-undangan Dalam Rangka Mengantisipasi Liberalisasi Perekonomian, Fakultas Hukum UNILA, Lampung, 1996, hlm. 16.

${ }^{8}$ Sjahran Basah, Eksistensi dan Tolok Ukur Badan Peradilan Administrasi Di Indonesia, Alumni, Bandung, 1986, hlm. 3.

${ }^{9}$ G. Bonoli, 2007. Time Matters: Post-Industrialization, New Social Risks, and Welfare State Adaptation inAdvanced Industrial Democracies. Comparative Political Studies, hlm 495-520.

${ }^{10}$ Ezekiel Mbitha Mwenzwa dan Sammy Mwangi Waweru, The Oscillating State's Role in the Provision of Social Welfare Services in Kenya, International Journal of Humanities and Social Science, Vol. 6, No. 5, May 2016, hlm. 126

${ }^{11}$ C.F.G. Sunaryati Hartono, Politik Hukum Menuju Satu Sistem Hukum Nasional, Alumni, Bandung, 1991, hlm. 2
} 
kerentanan sosial yang ditanggung oleh individu, keluarga, kelompok, dan/atau masyarakat sebagai dampak krisis sosial, krisis ekonomi, krisis politik, fenomena alam, wabah penyakit dan bencana alam yang jika tidak diberikan belanja bantuan sosial akan semakin terpuruk dan tidak dapat hidup dalam kondisi wajar. ${ }^{12}$

Belanja bantuan sosial terdiri atas berbagai bentuk, diantaranya adalah bantuan sosial yang bersifat konsumtif, bantuan sosial yang bersifat produktif, dan bantuan sosial melalui lembaga pendidikan, lembaga kesehatan dan lembaga tertentu. Belanja bantuan sosial yang bersifat konsumtif ditujukan untuk memenuhi kebutuhan hidup minimum masyarakat sebagai jaring pengaman sosial. Belanja bantuan sosial yang bersifat produktif ditujukan untuk membantu permodalan masyarakat ekonomi lemah. Pembayaran belanja bantuan sosial melalui lembaga pendidikan, lembaga kesehatan dan lembaga tertentu dilakukan melalui transfer uang, transfer barang, dan/atau transfer jasa. ${ }^{13}$

Peran pemerintah diperlukan dalam rangka melaksanakan penyaluran bantuan sosial maka Pemerintah harus terlebihdahulu menyusun petunjuk pelaksanaannya dan menetapkan para pihak maupun lembaga yang menjadi sasaran penerima bantuan. Selanjutnya ditentukan bentuk bantuannya, baik berupa transfer uang, barang maupun jasa, yang disalurkan secara langsung, melalui bank/pos penyalur maupun lembaga penyalur yang telah ditetapkan. Hal inidilakukan untukmenghindari adan penyimpangan dalam proses penyalurannya. ${ }^{14}$

Pemerintah telah menetapkan skema bantuan sosial untuk masyarakat selama Pandemi Corona Virus Disease2019 (covid-19), setidaknya ada 10 (sepuluh) bentuk bantuan sosial yang disalurkan oleh pemerintah, diantaranya adalah sebagai berikut: ${ }^{15}$

1) Program Keluarga Harapan (PKH) yang diberikan kepada 10 juta Keluarga Penerima Manfaat (KPM) dengan total anggaran sebesar Rp37,4 triliun. Sebelumnya, PKH ini disalurkan setiap 3 bulan, namun sekarang akan disalurkan setiap bulan mulai dari bulan April 2020.

2) Program Kartu Sembako yang diberikan kepada 20 juta warga negara Indonesia. Jadi, setiap orang mendapatkan Rp200.000 per bulan, mulai dari April sampai Desember 2020 dari anggaran sebesar Rp43,6 triliun. Sebelumnya program ini hanya diberikan kepada 15,2 juta masyarakat dengan besaran Rp150.000 per bulan sejak Januari sampai Februari.

3) Program Kartu Pra Kerja yang diberikan kepada 5,6 juta penerima manfaat dengan total anggaran Rp20 triliun. Besaran bantuan ini adalah Rp3,550,000 yang terdiri dari bantuan pelatihan sebesar Rp1.000.000, biaya penuntasan pelatihan sebesar Rp600.000 selama empat bulan, dan survei kebekerjaan sebesar Rp150.000.

${ }^{12}$ I Gede Made Artha Dharmakarja, Rekonstruksi Belanja Bantuan Sosial, Jurnal Substansi, Politeknik Keuangan Negara STAN, Terakreditasi Dikti Sinta 4, Volume 1 Nomor 2, 2017, hlm. 375

${ }^{13}$ I Gede Made Artha Dharmakarja, Ibid, hlm. 376

${ }^{14}$ I Gede Made Artha Dharmakarja, Ibid, hlm. 376

${ }^{15}$ Lihat dalam https://financer.com/id/10-bantuan-sosial-pemerintah-selama-pandemi-viruscorona/, diakses tgl 13 Mei 2020 
4) Program diskon token listrik 50\% hingga token listrik gratis selama 3 bulan untuk pelanggan Rumah Tangga. Diskon token listrik $50 \%$ bagi 7 juta pelanggan daya 900 VA. Sedangkan, listrik gratis untuk 24 juta pelanggan daya 450 VA. Program ini berjalan mulai dari bulan April sampai Juni 2020 dengan anggaran sebesar Rp3,5 triliun.

5) Program Pertamina bagi cashback $50 \%$ untuk driver ojek online sampai 12 Juli 2020. Program ini diberikan kepada 10 ribu driver ojol yang membeli bensin Pertalite, Pertamax, dan Pertamax Turbo setiap harinya lewat aplikasi MyPertamina. Total anggaran cashback yang diberikan oleh Pertamina untuk program ini sebesar Rp13,5 miliar.

6) Program Stimulus Kredit Usaha Rakyat (KUR) yang bertujuan untuk meringankan beban Usaha Mikro Kecil Menengah (UMKM). Kebijakan stimulus KUR ini diberikan dalam bentuk penundaan angsuran dan pembebasan bunga kredit selama 6 bulan.

7) Bantuan Sosial Baru, yaitu Bantuan Khusus Bahan Pokok Sembako dari Pemerintah Pusat yang diberikan kepada masyarakat di Jabodetabek dan di luar Jabodetabek. Bantuan sembako ini setara Rp600,000 per bulan yang diberikan selama 3 bulan.

8) Program Bantuan Dana Desa yang diberikan kepada 10 juta keluarga di desa dengan besaran Rp600,000 per bulan selama 3 bulan. Jumlah anggaran untuk Program Bantuan Dana Desa sebesar Rp21 triliun.

9) Program Keselamatan yang dilaksanakan oleh Kepolisian Negara Republik Indonesia (Polri). Bantuan ini mirip seperti Kartu Pra Kerja, namun akan ditujukan kepada 197 ribu pengemudi taksi, sopir bus, truk, dan kernet. Adapun insentifnya dalam bentuk uang Rp600,000 selama 3 bulan dengan total anggaran sebesar Rp360 miliar.

10) Program Padat Karya Tunai yang diharapkan untuk membantu mencetak lapangan kerja. Total anggaran ini sebesar Rp16,9 triliun yang tersebar di berbagai Kementerian. Contohnya, di Kementerian PUPR dengan Program Padat Karya Tunai yang menargetkan untuk mencetak 530 ribu tenaga kerja. Sedangkan Kementerian Desa dengan Program Padat Karya Tunai Desa yang menargetkan untuk mencetak 59 ribu pekerja.

Pendanaan yang besar dalam penanganan Pandemi Corona Virus Disease 2019 (covid-19), maka dibutuhkan Pengawasan dari pemerintah, salah satu cara untuk memperkuat kesetaraan dalam akses layanan penerima bantuan sosial. Dengan kontrol pemerintah maka pengawasan akan terorganisir dengan baik untuk setiap masyarakat terdampak pendemi ini.Ketua Gugus Tugas Percepatan Penanganan Covid-19, Doni Monardo meminta bahwa Komisi Pemberantasan Korupsi (KPK), Badan Pengawasan Keuangan dan Pembangunan (BPKP), dan Kejaksaan, untuk mengawasi aliran dana tersebut. ${ }^{16}$

Berdasarkan UU No. 25 Tahun 2009 tentang Pelayanan Publik, masyarakat diikutsertakan menjadi bagian dari pengawas eksternal bersama dengan Ombudsman, Dewan Perwakilan Rakyat (DPR), dan Dewan Perwakilan Rakyat

\footnotetext{
${ }^{16}$ Media Sustain, Peran Masyarakat Cegah Tindak Pidana Korupsi Terkait Pandemi Covid19, lihat dalam https://sustain.id/2020/04/23/peran-masyarakat-cegah-tindak-pidana-korupsiterkait-pandemi-covid-19/, diakses Tgl. 14 Maret 2020.
} 
Daerah (DPRD). Pengawasan oleh masyarakat dapat dilakukan dengan beberapa cara, seperti mencermati apakah aliran dana yang diberikan kepada masyarakat yang membutuhkan sudah tepat sasaran, apakah bantuan yang diterima nilainya wajar dan sesuai dengan yang dijanjikan atau diberitakan, serta terus mengikuti perkembangan berita melalui berbagai media daring.

Setiap warga negara mempunya hak dan kewajiban untuk berpartisipasi dalam memberikan laporan ini telah diatur dalam Peraturan Pemerintah No. 43 Tahun 2018. Pengganti Peraturan Pemerintah No. 71 Tahun 2000 ini menyatakan bahwa setiap warga negara Indonesia berhak menyampaikan keluhan, saran, atau kritik tentang upaya pencegahan dan pemberantasan tindak pidana korupsi yang dianggap tidak sesuai dengan peraturan perundang-undangan yang berlaku. Lebih lanjut, pemerintah juga akan memberikan hadiah berupa sejumlah uang dan piagam kepada pelapor jika kasus yang ia laporkan berhasil diputus bersalah oleh pengadilan. ${ }^{17}$

\section{b) Peran Pemerintah dan Masyarakat Dalam PengawasanBantuan Sosial}

Melihat besarnya bantuan sosial yang diberikan selama Pandemi Corona Virus Disease 2019 (covid-19), maka perlu juga ditelisik kondisi keuangan negara. Keuangannegaramerupakanlembaga yang sangat vital dalam suatu negara, karena lembaga ini berkaitan erat dengan tujuan negara dan bagaimana kas negara yang diisi dari uang rakyat itu dikelola untuk memutar roda pemerintahan dan pembangunan. Apabilakeuangannegara tidak dikelola dengan baik, konsekuensi logisnyatujuannegaratidakakantercapai. Pengelolaan keuangan merupakan salah satu kunci keberhasilan pembangunan dan penyelenggaraan pemerintah dalam kerangka nation dan state building. Adanya pengelolaan keuangan yang baik akan menjamin tercapainya tujuan pembangunan secara khusus, dan tujuan berbangsa danbernegara secara umum. Negara merupakan suatu organisasi yang unik, yang memiliki otoritas yang bersifat memaksa di atas subjek hukum pribadi yang menjadiwarga negaranya. Walaudemikianpengurusan,pengelolaan atau penyelenggaraan jalannya negara tidak luput dari mekanisme pertanggungjawaban oleh para pengurus, pengelola dan penyelenggara negara. ${ }^{18}$

Suatu perbuatan menyalahgunakan dan penyelewengan bantuan sosial tentunya sangat tercela. Idealnya negara hukum dan menjunjung nilai-nilai yang hidup dalam masyarakat, Bantuan sosial selayaknya digunakan sesuai peruntukan yang diatur dalam peraturan di Indonesia.IKesalahan dalam pengelolaan keuangan negara menyebabkan penggunaanya menjadi tidak tepat sasaran dan menimbulkan kerugian negara. kesalahan terjadi karena pelakunya melakukan kesengajaan atau kelalaian dalam mengelola keuangan negara. keterkaitan hukum pidana dalam masalah kerugian negara karena perbuatan itu dilakukan untuk memperkaya diri

\section{${ }^{17}$ Ibid.}

${ }^{18}$ Holmes Sianturi, Kedudukan Keuangan Daerah Dalam Pengelolaan Dana Hibah Dan Bantuan Sosial Berdasarkan Perspektif Keuangan Negara, Jurnal Wawasan Yuridika, STIH Bandung, Vol. 1. No.1. Maret 2017, hlm. 87. Lihat juga Gunawan Widjaja, Seri Keuangan Publik: Pengelolaan Kekayaan Negara Suatu Tinjauan Yuridis, RajaGrafindo Persada, Jakarta, 2002, hlm. 2 
sendiri, orang lain, korporasi yang menimbulkan kerugian keuangan negara dan bahkan perekonomian negara. ${ }^{19}$

Ketentuan pidana yang termuat dalam Undang-Undang No.15 Tahun 2004 Tentang pemeriksaan pengelolaan dan pertanggungjawaban keuangan negara atau disingkat dengan UUP3KN, merupakan instrumen hukum yang bersifat primum remedium, bukan bersifat ultimum remedium. Dalam arti ketika terjadi perbuatan dalam pemeriksaan pengelolaan dan pertanggungjawaban keuangan negara yang terjaring masuk ke dalam ketentuan pidana UUP3KN, harus dilakukan penyelesaian berdasarkan pasal-pasal yang terkait dengan perbuatan itu, di sini letak sifat primum remedium dibandingkan dengan sifat ultimum remedium karena berkaitan dengan perbuatan pada saat dilakukan pemeriksaan pengelolaan dan pertanggungjawaban keuangan negara. ${ }^{20}$

Oleh sebab itu, pengguanaan hukum pidana sebagai salah satu upaya untuk mengatasi masalah sosial termasuk dalam bidang kebijakan penegakan hukum. Maka kebijakan penegakan hukum pidana termasuk dalam kebijakan sosial, yaitu segala usaha yang rasional untuk mencapai kesejahteraan masyarakat, tetapi tidakada kemutlakan dalam kebijakan hukum pidana. dengan demikian penggunaan hukum pidana merupakan masalah kebijakan (the problem of policy). ${ }^{21}$

Oleh karenanya pengelolaan keuangan negara khususnya keuangan daerah berada dalam dimensi penghargaan dan perlindungan terhadap masyarakat yang sedang membutuhkan bantuan sosial baik dalam ekonomi, sosial dan budaya baik yang mengandung resiko maupun tidak, ruang lingkup pengelolaan keuangan meliputi perencanaan, pelaksanaan, pengawasaan dan pertanggungjawaban keuangan, pengawasan adalah upaya agar sesuatu dilaksanakan sesuai dengan peraturan yang telah ditetapkan dan instruksi yang telah dikeluarkan. ${ }^{22}$ Khsusus dalam pengelolaan bantuan sosial yang berpotensi korupsi akibat diselewengkan.

Pemberian bantuan sosial diberikan secara selektif, memenuhi persyaratan penerima bantuan, bersifat sementara dan tidak terus menerus, kecuali dalam keadaan tertentu dapat berkelanjutan, sesuai tujuan penggunaan yang bertujuan untuk melindungi dari kemungkinan resiko sosial. Dana bantuan sosial diberikan kepada masyarakat yang memiliki identitas yang jelas dan bertempat tinggal di wilayah Indonesia, agar penggunaan anggaran dana bantuan sosial dapat lebih efektif. Pemberian bansos berkriteria selektif artinya bansos hanya ditujukan untuk melindungi dari kemungkinan resiko sosial. ${ }^{23}$

Agar bantuan sosial bisa dilaksanakan dengan akuntabel, transparan, dan berpegang pada prinsip berkeadilan perlu dibentuk suatu Tim verifikasi independen yang akan menilai secara selektif baik kriteria penerima maupun dari segi proposal $70-71$

${ }^{19}$ Muhammad Djafar Saidi, Hukum Keuangan Negara, Jakarta: Rajawali Pers, 2008, hlm.

${ }^{20}$ Ibid, hlm. 149-150

${ }^{21}$ Barda Nawawi Arief, Kebijakan Legislatif dalam Penanggulangan Kejahatan dengan Pidana Penjara, Yogyakarta: Genta Publishing, 2010, hlm. 17-18

${ }^{22}$ Karmila dan Cokorda Dalem Dahana, Kebijakan Pemerintah Daerah Provinsi Bali Terhadap Pemberian Dana Bantuan Sosial, Jurnal Kertha Negara Fakultas Hukum Universitas Udayana, Vol. 06, No. 01, Januari 2018, hlm. 9. Lihat juga M. Djafar Saidi, 2011, Hukum Keuangan Negara, Raja Grafindo Persada, Jakarta, hlm.15.

${ }^{23}$ Ibid, hlm. 7 
bantuan sosial itu sendiri.Masalah pengelolaan dan pertanggungjawaban juga harus ditempatkan sebagai upaya membangun komitmen awal yang baik untuk mengurangi tingkat penyelewengan. Bantuan sosial adalah bagian dari APBN/APBD, untuk itu, mentalitas pengelola perlu diperbaiki, dan mekanisme pengawasan harus lebih diperkuat baik oleh Bawasda atau BPKP (Badan Pengawasan Keuangan dan Pembangunan).Selain itu, Bantuan Sosial harus memiliki nilai edukasi kepada masyarakat. Publikasi tentang Bantuan Sosial harus dilakukan secara komprehensif, sehingga masyarakat bisa melakukan social control dan memberikan feed back. ${ }^{24}$

Menteri Keuangan Sri Mulyani, menyebutkan bahwa Kebijakan pemerintah yang tertuang dalam Inpres Nomor 4 Tahun 2020 tentang Refocussing Kegiatan, Realokasi Anggaran serta Pengadaan Barang dan Jasa dalam rangka Percepatan Penanganan Corona Virus Disease 2019 (COVID-19), akan membuka "celah korupsi" bagi oknum-oknum tertentu. Makanya, ia menegaskan pemerintah akan menindak tegas pihak-pihak yang mengambil keuntungan di tengah penanganan virus corona.maka untuk itu, Pemerintah mengawasi dengan ketat pelaksanaan pengalihan anggaran, baik di pusat maupun daerah. Jangan sampai pemerintah terlena dengan terus mengeluarkan kebijakan baru, tapi abai melakukan pengawasan. $^{25}$

Lembaga pemerintahan yang bertugas mencegah tindakan korupsi dan memeriksa keuangan negara juga perlu bekerja lebih ekstra untuk memantau realokasi anggaran dan implementasinya dalam penanganan virus corona. Lembaga yang dimaksud adalah Komisi Pemberantasan Korupsi (KPK), Badan Pemeriksa Keuangan (BPK), dan Badan Pengawasan Keuangan dan Pembangunan (BPKP).

Kementerian Dalam Negeri (Kemendagri) mengakui ada aturan yang tidak selaras dengan Kementerian Desa, Pembangunan Daerah Tertinggal, dan Transmigrasi (Kemendes PDTT) terkait mekanisme distribusi bantuan sosial kepada warga terdampak virus korona (covid-19) di desa.Aturan yang tak selaras itu, yakni Instruksi Mendagri Nomor 3 Tahun 2020 tentang Penanggulangan Korona (Covid-19) di Desa melalui Anggaran Pendapatan dan Belanja Desa, dan Permendes PDTT Nomor 6 Tahun 2020 tentang Perubahan Atas Permendes PDTT Nomor 11 Tahun 2019 tentang Prioritas Penggunaan Dana Desa Tahun 2020. Kemendagri hanya mengatur ruang lingkup pengelolaan keuangan desa. Kemendagri tak mengatur kriteria dan mekanisme pendataan kepala keluarga penerima bantuan langsung tunai (BLT) dana desa. ${ }^{26}$

Untuk mewujudkan suasana tertib itu, maka pelbagai program dan kebijaksanaan pembangunan negara perlu didukung dan ditegakkan oleh seperangkat kaidah peraturan perundang-undangan yang antara lain memuat aturan

24 BPKP: Filosofi Bantuan Sosial berbeda dengan Hibah, Dalam http://www.bpkp.go.id/berita/read/2778/6370/BPKP-Filosofi-Bantuan-Sosial-berbeda-denganHibah.bpkp, diakses, Tg. 13 Mei 2020

${ }^{25}$ CNN Indonesia, Hati-hati, Dana Penanganan Wabah Corona Rawan Korupsi, Dalam https://www.cnnindonesia.com /ekonomi/ 20200326075745-532-486933/ hati-hati- danapenanganan- wabah-corona- rawan-korupsi, Diakses Tgl. 12 Mei 2020

${ }^{26}$ Media Lampost. Co, Kemendagri Mengakui Ada Aturan Tak Selaras Terkait Bansos, Dalam https://www.lampost.co/berita-kemendagri-mengakui-ada-aturan-tak-selaras-terkaitbansos.html, diakses Tgl. 11 Mei 2020 
dan pola perilaku-perilaku tertentu, berupa larangan-larangan, kewajibankewajiban dan anjuran-anjuran. Tiada gunanya memberlakukan kaidah-kaidah hukum manakala kaidah-kaidah itu tidak dapat dipaksakan melalui sanksi dan menegakkan kaidah-kaidah dimaksud secara prosedural (hukum acara). ${ }^{27}$

Begitu pula dalam penanganan berbagai kasus korupsi, maka hukum harus ditegakkan sebagaimana yang digariskan oleh hukum. Penegakan hukum selalu melibatkan manusia didalamnya dan melibatkan juga tingkah laku manusia. Hukum tidak dapat tegak dengan sendirinya, artinya hukum tidak mampu mewujudkan sendiri janji-janji serta kehendak-kehendak yang tercantum dalam (peraturanperaturan) hukum. Janji dan kehendak tersebut, misalnya untuk memberikan hak kepada seseorang, mengenakan pidana terhadap seorang yang memenuhi persyaratan tertentu dan sebagainya. ${ }^{28}$

Perkembangan korupsi sampai saat ini sudah merupakan akibat dari sistem penyelenggaraan pemerintahan yang tidak tertata secara tertib dan tidak terawasi secara baik, karena landasan hukum yang dipergunakan juga mengandung banyak kelemahan dalam implementasinya. Dalam upaya untuk mempercepat tercapainya kesejahteraan sosial sebagaimana diamanatkan oleh Pembukaan UUD 1945 perlu adanya usaha untuk mempercepat pemberantasan korupsi, melalui implementasi undang-undang korupsi terhadap pelaku tindak pidana korupsi. ${ }^{29}$

Perbuatan korupsi harus memenuhi 4 (empat) unsur: ${ }^{30}$

1. Niat melakukan korupsi (desire to act): unsur ini berada didalam diri seseorang, dibentuk dalam waktu yang panjang dimulai sejak kecil. Ini sangat berkaitan dengan tiga macam teori tentang mengapa seseorang menjadi penjahat. Pertama, penjahat itu dilahirkan (the born criminal). Ini disebut juga teori bakat, yaitu seseorang sejak lahirnya telah memiliki sifat jahat. Kedua, penjahat yang terbentuk oleh lingkungan. Anak yang lahir dari lingkungan baik-baik akan jahat apabila berada dalam lingkungan penjahat. Ini biasanya disebut teori tabularasa, bahwa seseorang dilahirkan kedunia dalam keadaan bersih ibarat kertas putih, selanjutnya tergantung lingkungan yang membuatnya menjadi berwarna. Itulah sebabnya di beberapa negara maju, penjahat pemula tak dimasukkan kedalam penjara agar tidak bertambah jahat. Ketiga, teori campuran antara bakat dan lingkungan.

2. Kemampuan untuk berbuat korupsi (ability to act): faktor ini senyatanya dapat disubtitusikan melalui penggunaan orang lain yang memiliki kemampuan yang diperlukan untuk berbuat jahat. Misalnya dengan jalan disewa, dipaksa atau dijanjikan sesuatu yang menarik apabila yang bersangkutan mau melakukan

${ }^{27}$ Fitriana Murniati, Kebijakan Formulasi Hukum Pidana Administrasi Dalam Bidang Kesehatan Di Indonesia, Tesis Pada Program Pascasarjana Fakultas Hukum Universitas Diponegoro, 2007, hlm. 48

${ }^{28}$ Satjipto Rahardjo, Penegakan Hukum Suatu Tinjauan Sosiologis, Yogyakarta: Genta Publishing, 2009, hlm. 7

${ }_{29}$ Muhammad Nur, Kebijakan Hukum Pidana Terhadap Pemberantasan Tindak Pidana Korupsi, Dalam Jurnal Reusam Fakultas Hukum Universitas Malikussaleh, Vol. 1 No. 2 November 2013, hlm. 73

${ }^{30}$ Bibit S. Riyanto, Koruptor Go To Hell: Mengupas Anatomi Korupsi Di Indonesia, (Bandung: Mizan Media Utama, 2009), hlm. 14-20 
pekerjaan itu dengan menggunakan keahlian, kemampuan, atau kewenangan yang dimilikinya.

3. Peluang atau kesempatan untuk melakukan korupsi (opportunity to do corruption): ini dimiliki oleh orang memiliki kewenangan pada setiap jenjang kekuasaan. Peluang akan menjadi makin besar apabila:

a. Ketentuan yang berlaku sangat longgar dalam arti dapat memberi peluang melakukan korupsi

b. Diawaki oleh pejabat yang koruptif

c. Ada sesuatu yang dikorupsi

d. Orang-orang yang berhubungan dengan kekuasaan bisa menerima kondisi koruptif sebagai prasyarat untuk berhubungan dengan kekuasan tersebut (dalam arti tidak mempersoalkannya atau malah mendorong terjadinya kondisi demikian)

e. Rendahnya kualitas pengawasan internal maupun eksternal (social control).

4. Target atau adanya sasaran yang bisa dikorupsi (suitable target): unsur ini tidak dapat disubtitusikan, tapi dapat diciptakan oleh sipemilik kewenangan atau kekuasaan. Unsur ini dapat dilakukan sendiri atau bersama-sama dengan orang lain. Misalnya, kewenangan menentukan anggaran pendapatan dan belanja. Didalam menentukan program dan besaran anggaran terjadi negosiasi (lobby), antara pembela dan penyidik untuk penentuan pasal yang dilanggar pelaku, pembela dengan penuntut umum untuk menentukan dakwaan, antara pengacara dan hakim untuk menentukan putusan, antara panitia dan peserta tender suatu proyek yang ditenderkan, antara bawahan dan atasan agar mendapatkan promosi, antara peminta izin dan si pembuat izin, atau antara calon pejabat dan pemilih, dan sebagainya.

Menyikapi persoalan munculnya celah korupsi dalam penggunaan anggaran dan bantuan sosial kepada masyarakat, KPK melalui Surat Edaran No. 11 Tahun 2020, tanggal 21 April 2020 tentang Penggunaan Data Terpadu Kesejahteraan Sosial (DTKS) dan data non-DTKS dalam pemberian Bantuan Sosial kepada masyarakat dalam upaya mengatasi dampak pandemik global Corona Virus Disease 2019 (COVID-19). yang ditujukan kepada Ketua Gugus Tugas Percepatan Penanganan Covid-19 baik di tingkat nasional maupun daerah, dan pimpinan kementerian/lembaga/pemerintah daerah tersebut, KPK merekomendasikan 5 (lima) hal agar pendataan dan penyaluran bansos tepat sasaran, yaitu sebagai berikut: ${ }^{31}$

1. Kementerian/Lembaga dan Pemerintah daerah dapat melakukan pendataan di lapangan, namun tetap merujuk kepada DTKS. Jika ditemukan ketidaksesuaian, bantuan tetap dapat diberikan dan data penerima bantuan baru tersebut harus dilaporkan kepada Dinas Sosial atau Pusat Data dan Informasi Kesejahteraan Sosial (Pusdatin) Kementerian Sosial untuk diusulkan masuk ke dalam DTKS sesuai peraturan yang berlaku.

\footnotetext{
${ }^{31}$ Komisi Pemberantasan Korupsi, KPK Ingatkan Pemerintah Pastikan Data Penerima Bantuan Sosial, Lihat Juga dalam https://www.kpk.go.id/id/berita/siaran-pers/1600-kpk-ingatkanpemerintah-pastikan-data-penerima-bantuan-sosial, Diakses Tg. 10 Mei 2020
} 
2. Namun sebaliknya, jika penerima bantuan terdaftar pada DTKS namun fakta di lapangan tidak memenuhi syarat sebagai penerima bantuan, maka harus dilaporkan ke Dinsos/Pusdatin untuk perbaikan DTKS.

3. Untuk memastikan data valid maka data penerima bansos dari program-program lainnya atau data hasil pengumpulan di lapangan agar dipadankan data NIK-nya dengan data Dinas Kependudukan dan Catatan Sipil setempat.

4. Kementerian/Lembaga dan pemerintah daerah menjamin keterbukaan akses data tentang penerima bantuan, realisasi bantuan dan anggaran yang tersedia kepada masyarakat sebagai bentuk transparansi dan akuntabilitas.

5. KPK mendorong pelibatan dan peningkatan peran serta masyarakat untuk mengawasi. Untuk itu, kementerian/lembaga dan pemda perlu menyediakan sarana layanan pengaduan masyarakat yang mudah, murah dan dapat ditindaklanjuti setiap laporan dan pengaduan masyarakat.

Berkaitan dengan pengaduan masyarakat terhadap dugaan adanya indikasi penyimpangan dalam penyaluran bantuan sosial pandemik global Corona Virus Disease 2019 (COVID-19) maka perlu diperhatikan prinsip-prinsip yang digunakan dalam pengelolaan pengaduan Bantuan sosial adalah: ${ }^{32}$

1. Rahasia, identitas pengadu dirahasiakan, kecuali pengadu menghendaki sebaliknya.

2. Berjenjang, pengaduan yang masuk ditangani oleh pengelola pengaduan Bansos Pangan pada jenjang dimana peristiwa yang diadukan tersebut terjadi. Apabila pengaduan tidak berhasil diselesaikan pada jenjang tersebut, maka pengaduan dibawa ke jenjang di atasnya.

3. Transparansi, sedapat mungkin masyarakat harus diberitahu dan dilibatkan dalam proses penanganan pengaduan. Pengadu akan mendapatkan informasi tentang proses dan hasil penanganan pengaduan.

4. Proporsional, penanganan pengaduan harus sesuai dengan ruang lingkup kasusnya.

5. Akuntabel, proses pengelolaan pengaduan dan tindak lanjutnya harus dapat dipertanggungjawabkan kepada masyarakat.

6. Objektif, penanganan pengaduan ditangani secara adil dan tidak memihak.

7. Kemudahan, sistem pengaduan dirancang untuk memudahkan masyarakat menyampaikan pengaduan dengan menyediakan berbagai media dan saluran pengaduan di setiap jenjang.

8. Kerjasama, bahwa kegiatan penanganan pengaduan masyarakat harus dilaksanakan dengan kerjasama yang baik antar pejabat yang berwenang dan terkait berdasarkan mekanisme, tata kerja dan prosedur yang berlaku.

9. Cepat dan akurat, setiap pengaduan ditangani secara cepat berdasarkan informasi yang akurat.

10. Tercatat, seluruh pengaduan dicatat (secara elektronik) dan dapat ditelusuri proses penanganannya.

\footnotetext{
${ }^{32}$ Kementerian Koordinator Bidang Pembangunan Manusia dan Kebudayaan RI, Pedoman Khusus Pengelolaan Pengaduan Bantuan sosial pangan, Kementerian Koordinator Bidang Pembangunan Manusia dan Kebudayaan RI, Kementerian Dalam Negeri RI dan Kementerian Sosial RI, Maret 2018, hlm. 12
} 
Peran penting pengawasan yang dilakukan oleh masyarakat terhadap penyelenggaraan pemerintah daerah merupakan suatu upaya penerapan tata pemerintahan yang baik (good govermance) guna menciptakan pemerintahan yang bersih dari korupsi, kolusi dan nepotisme. Untuk mewujudkan penyelenggara yang bersih dan bebas dari korupsi peran masyarakat menjadi penting untuk diberi ruang luas terhadap peran serta masyarakat. Pemberian ruang kepada masyarakat untuk berperan serta, ini sesuai dengan prinsip keterbukaan dalam negara demokrasi. Prinsip ini mengharuskan penyelenggara negara untuk membuka ruang terhadap hak masyarakat untuk memperoleh informasi yang benar, jujur, dan tidak diskriminamatif. Peran serta masyarakat dalam mewujudkan pemerintahan yang bersih dan berwibawa. Menurut Peraturan Pemerintah Nomor 68 Tahun 1999 Tentang Tata Cara Pelaksanaan Peran Masyarakat Dalam Penyelenggaraan Negara dinyatakan bahwa yang dimaksud dengan peranserta mewujudkan Penyelenggara Negara yang bersih dan berwibawa yang dilaksanakan dengan menaati norma hukum, moral, dan sosial yang berlaku dalam masyarakat. ${ }^{33}$

Partisipasi masyarakat umum dalam penyelenggaraan negara memberikan jaminan supaya tercapainya Indonesia yang lebih baik terutama ditengah negara dalam kondisi pandemi corona. masyarakat juga menginginkan kesempatan untuk berperan aktif dalam menjalankan setiap ketentuan-ketentuan yang dikeluarkan pemerintah. Masyarakat tidak hanya menunggu haknya diwujudkan tetapi juga menjalankan kewajiban. Pemerintah juga tidak hanya memberikan perintah dalam bentuk peraturan tetapi juga memperhatikan kesejateraan rakyat. ${ }^{34}$

Oleh sebab itu, dalam memperkuat kesejahteraan sosial dan pengawasan pengelolaan bantuan sosial ditengah pandemik global Corona Virus Disease 2019 (COVID-19) harus terus dtingkatkan, hal ini disebabkan pengawasan pengelolaan keuangan saat ini masih rentan untuk terjadinya tindak pidana korupsi. Banyak kasus-kasus korupsi yang bersumber dari bantuan sosial sudah diproses hukum dan ini penting untuk menjadi perhatian bersama.

\section{Penutup}

Bantuan sosial merupakan bagian dari kesejahteraan sosial sebagai tujuan dari negara hukum tidak dapat dilepaskan dari konsep kejahatan. Secara umum konsep kejahatan dapat dikatakan berhubungan dengan keadaan tidak terwujudnya kesejahteraan sosial pada tataran individu, kelompok maupun bangsa. Secara lebih mendasar perwujudan kesejahteraan sosial berhubungan dengan pemenuhan hak asasi manusia dan moralitas dari penyelenggara negara.

Pengelolaan keuangan negara/daerah merupakan salah satu hal yang sangat penting bagi kehidupan perekonomian suatu negara. Misalnya, bantaun sosial yang dianggarakan harus mendapat pengawasan baik oleh pemerintah maupun masyarakat. Lembaga pemerintahan yang bertugas mencegah tindakan korupsi dan memeriksa keuangan negara juga perlu bekerja lebih ekstra untuk memantau

\footnotetext{
${ }^{33}$ Ilvana Natalia Natarang. Kajian Yuridis Terhadap Penyimpangan Bantuan Sosial Desa Menurut Undang- Undang Nomor 31 Tahun 1999 Jo Undang-Undang Nomor 20 Tahun 2001

Tentang tindak pidana korupsi, Jurnal Lex Crimen Vol. VII/No. 10/Des/2018,Bagian Hukum Pidana Fakultas Hukum Universitas Sam Ratulangi, Manado, hlm. 76

${ }^{34}$ Ibid, hlm. 78
} 
realokasi anggaran dan implementasinya dalam penanganan virus corona. Lembaga yang dimaksud adalah Komisi Pemberantasan Korupsi (KPK), Badan Pemeriksa Keuangan (BPK), dan Badan Pengawasan Keuangan dan Pembangunan (BPKP).

Selanjutnya adalah, pemerintah perlu memprioritaskan program peningkatan manajemen data terutama data penerima bantuan sosial. Pendataan yang akurat penting untuk dijalankan agar data pemerintah dapat dikelola dengan baik. Dengan manajemen data yang baik dan dapat dibagikan, pemerintah dapat memberikan data secara terbuka kepada publik.

\section{DAFTAR PUSTAKA}

\section{Buku}

Basah, Sjahran, 1986, Eksistensi dan Tolok Ukur Badan Peradilan Administrasi Di Indonesia, Alumni, Bandung.

Bonoli, G, 2007. Time Matters: Post-Industrialization, New Social Risks, and Welfare State Adaptation inAdvanced Industrial Democracies. Comparative Political Studies.

Djafar Saidi, Muhammad, 2008, Hukum Keuangan Negara, Rajawali Pers, Jakarta. Djafar Saidi, M., 2011, Hukum Keuangan Negara, Raja Grafindo Persada, Jakarta.

Kementerian Koordinator Bidang Pembangunan Manusia dan Kebudayaan RI, 2018, Pedoman Khusus Pengelolaan Pengaduan Bantuan sosial pangan, Jakarta, Kementerian Dalam Negeri RI dan Kementerian Sosial RI.

Manan, Bagir, 1996, Politik Perundang-undangan Dalam Rangka Mengantisipasi Liberalisasi Perekonomian, Fakultas Hukum UNILA, Lampung.

Nawawi Arief, Barda, 2010, Kebijakan Legislatif dalam Penanggulangan Kejahatan dengan Pidana Penjara, Genta Publishing, Yogyakarta.

Rahardjo, Satjipto, 2009, Penegakan Hukum Suatu Tinjauan Sosiologis, Genta Publishing, Yogyakarta.

Riyanto, Bibit S., 2009, Koruptor Go To Hell: Mengupas Anatomi Korupsi di Indonesia, Mizan Media Utama, Bandung.

Sunaryati Hartono, C.F.G, 1991, Politik Hukum Menuju Satu Sistem Hukum Nasional, Alumni, Bandung.

Widjaja, Gunawan, 2002, Seri Keuangan Publik: Pengelolaan Kekayaan Negara Suatu Tinjauan Yuridis, RajaGrafindo Persada, Jakarta.

\section{Artikel Jurnal}

Artha Dharmakarja,I Gede Made, Rekonstruksi Belanja Bantuan Sosial, Jurnal Substansi, Politeknik Keuangan Negara STAN, Terakreditasi Dikti Sinta 4, Volume 1 Nomor 2, 2017.

Karmila dan Cokorda Dalem Dahana, Kebijakan Pemerintah Daerah Provinsi Bali Terhadap Pemberian Dana Bantuan Sosial, Jurnal Kertha Negara Fakultas Hukum Universitas Udayana, Vol. 06, No. 01, Januari 2018. 
Mwenzwa, Ezekiel Mbitha dan Sammy Mwangi Waweru, The Oscillating State's Role in the Provision of Social Welfare Services in Kenya, International Journal of Humanities and Social Science, Vol. 6, No. 5, May 2016.

Natalia Natarang. Ilvana, Kajian Yuridis Terhadap Penyimpangan Bantuan Sosial Desa Menurut Undang-Undang Nomor 31 Tahun 1999 Jo Undang-Undang Nomor 20 Tahun 2001Tentang tindak pidana korupsi, Jurnal Lex Crimen Vol. VII/No. 10/Des/2018.

Nur,Muhammad, Kebijakan Hukum Pidana Terhadap Pemberantasan Tindak Pidana Korupsi, Dalam Jurnal Reusam Fakultas Hukum Universitas Malikussaleh, Vol. 1 No. 2 November 2013.

Sianturi,Holmes, Kedudukan Keuangan Daerah Dalam Pengelolaan Dana Hibah Dan Bantuan Sosial Berdasarkan Perspektif Keuangan Negara, Jurnal Wawasan Yuridika, STIH Bandung, Vol. 1. No.1. Maret 2017.

\section{Internet}

BPKP: Filosofi Bantuan Sosial berbeda dengan Hibah, Dalam http://www.bpkp.go.id/berita/read/2778/6370/BPKP-Filosofi-Bantuan-

Sosial-berbeda-dengan-Hibah.bpkp, diakses, Tg. 13 Mei 2020.

CNN Indonesia, Hati-hati, Dana Penanganan Wabah Corona Rawan Korupsi, Dalam https://www.cnnindonesia.com /ekonomi/ 20200326075745-532486933/ hati-hati- dana-penanganan- wabah-corona- rawan-korupsi, Diakses Tgl. 12 Mei 2020.

https://financer.com/id/10- bantuan-sosial- pemerintah-selama-pandemi-viruscorona/, diakses tgl 13 Mei 2020.

Komisi Pemberantasan Korupsi, KPK Ingatkan Pemerintah Pastikan Data Penerima Bantuan Sosial, Lihat Juga dalam https://www.kpk.go.id/id/berita/siaran-pers/1600-kpk-ingatkan-pemerintahpastikan- data-penerima-bantuan-sosial, Diakses Tg. 10 Mei 2020

Muhammad Fatahillah Akbar, Tanggung Jawab Hukum dalam Wabah Corona, Kolom Koran Tempo, Tgl. 30 Maret 2020. Bisa diakses melalui https://kolom.tempo.co/read/ 1325429/tanggung-jawab-hukum-dalamwabah-corona/full\&view=ok, Diakses Tgl. 9 Mei 2020.

Media Berita Satu, Terkait Bansos, KPK Kaji Temuan BPK Adanya Potensi Kerugian Negara $R p \quad 843,7 \quad M$, Lihat juga dalam: https://www.beritasatu.com/ nasional/631075- terkait-bansos-kpk-kajitemuan- bpk-adanya-potensi- kerugian-negara-rp-8437-m, Diakses Tgl. 10 mei 2020.

Media Sustain, Peran Masyarakat Cegah Tindak Pidana Korupsi Terkait Pandemi Covid-19, lihat dalam https://sustain.id/2020/04/23/peran-masyarakat-cegah -tindak-pidana-korupsi -terkait-pandemi-covid-19/, diakses Tgl. 14 Maret 2020.

Media Lampost. Co, Kemendagri Mengakui Ada Aturan Tak Selaras Terkait Bansos, Dalam https://www.lampost.co/berita-kemendagri-mengakui-adaaturan-tak-selaras-terkait-bansos.html, diakses Tgl. 11 Mei 2020.

Today Line, Ombudsman Terima Aduan Petugas Salurkan Bansos Minta Imbalan ke Penerima, lihat dalam https://today.line. me/id/pc/article/ Ombudsman+ 
Terima+

Aduan+

Petugas+

Salurkan+

Bansos+Minta+Imbalan+ke+Penerima-wMNILG, diakses Tgl. 13 Mei 2020 .

\section{Hasil Penelitian/Tugas Akhir}

Fitriana Murniati, 2007, "Kebijakan Formulasi Hukum Pidana Administrasi Dalam

Bidang Kesehatan di Indonesia", Tesis Pada Program Pascasarjana Fakultas Hukum Universitas Diponegoro. 